Rethinking Urban Democracy in South Asia

\title{
Bystander Tactics: Life on Turf in Karachi
}

\section{Tania Ahmad}

\section{OpenEdition}

\section{Journals}

Electronic version

URL: http://journals.openedition.org/samaj/3537

DOI: $10.4000 /$ samaj.3537

ISSN: 1960-6060

\section{Publisher}

Association pour la recherche sur l'Asie du Sud (ARAS)

\section{Electronic reference}

Tania Ahmad, « Bystander Tactics: Life on Turf in Karachi », South Asia Multidisciplinary Academic Journal [Online], 5 | 2011, Online since 30 December 2011, connection on 30 April 2019. URL : http:// journals.openedition.org/samaj/3537 ; DOI : 10.4000/samaj.3537

This text was automatically generated on 30 April 2019.

\section{(c) $(1) \odot$}

This work is licensed under a Creative Commons Attribution-NonCommercial-NoDerivatives 4.0 International License. 


\title{
Bystander Tactics: Life on Turf in Karachi
}

\author{
Tania Ahmad
}

Acknowledgments: I would like to thank the anonymous reviewers and editors of SAMAJ for their valuable feedback in developing this paper. For their comments and support on earlier versions of this material, my gratitude goes to Zhanara Nauruzbayeva, Shahzad Bashir, Noman Baig, Mun Young Cho and Dolly Kikon, as well as Nosheen Ali, Nikhil Anand, Ulka Anjaria, Matthew Hull, S. Mubbashir Rizvi and Sylvia Yanagisako. For their careful attention to and discussion of an early presentation of these findings, my appreciation goes to the graduate students in the Department of Anthropology at Stanford University.

1 Among middle-class Karachi residents, membership in political parties, or issues which referred to party politics, are avoided with a vigor that seems out of place in a city where neighborhoods were associated with political affiliations that were both commonly known and displayed. During research conducted in 2006-07, although my informants conveyed political sympathies through either vocally opinionated conviction or by association with affiliated relatives, they also actively resisted formal involvement in party work. A legacy of violent student politics in the 1980s and 1990s had resulted in particular sites, like Karachi University, being heavily policed by federally appointed paramilitary Rangers. At a major women's community center, the official rules stated that any mention of either political or religious issues within the compound was prohibited and grounds for expulsion. In alternative impassioned accounts, parents and schoolteachers discussed the vigilance necessary to keep their sons from being recruited into party politics. The major way they managed, they said, was to keep their loved ones in controlled spaces, often inside their homes. These are common, if underrepresented, experiences of everyday life in urban Pakistan. It is imperative for analyses of democratization to draw sustained attention to how bystanders cede to and thus enable political violence precisely in the moments that they seek to avoid vulnerability.

2 This article is about evasive maneuverings. Infamous for its territorialized politics, extremes of social inequality and variably regulated urban sprawl, Karachi is equally marked by the resilience of its residents in the face of now-predictable assertions about 
crisis, failure and instability. ${ }^{1}$ While an important legacy of scholarship has investigated the processes of how and why people subscribe to organized identity politics in Karachi, ${ }^{2} \mathrm{I}$ examine the important category of those who do not. In contrast to the more elaborately defined categories of victims and perpetrators of political violence, I focus on the interstitial position of bystanders as a sustained mode of participation through practices of complicity, subjection and subversion. ${ }^{3}$ Here, I argue that the bystander is engaged in a tactics of anticipation and interpretation to assess and react to 'possibly benign but potentially malevolent situations' (Naveeda Khan 2006). Discourses and practices of standing by, remaining aloof or avoiding political affiliation by Karachi residents living on party turf articulate the tense interstices between political mobilization and 'everyday peace' (Ring 2006). The ordinariness of everyday life, as Veena Das (2007) reminds us, is an achievement; the outcome of ongoing processes of enfolding that incorporate as they re-make past ruptures into the renewed temporalities of daily experience. Das emphasizes a definitive afterward, through which the temporality of a rupture remembered is enfolded in the activities and silences of the ordinary. Rather than a clear aftermath, however, Karachi residents emphasized an ongoing play of contingencies, of successive ruptures at alternate scales, and the activities of anticipation that were at least as formative as the contingent futures which they hoped to buffer.

3 The bystander, as an analytical concept, has been used in a number of disciplinary contexts to develop theories of participation that do not map onto the categories of victim and perpetrator. ${ }^{4}$ Notably, genocide research and holocaust studies hinge on a consideration of bystanders as liminal positions that combine indirect forms of complicity and subversion (e.g. Ehrenreich \& Cole 2005, Staub 1989, 1996, Vetlesen 2000, 2005). ${ }^{5}$ This literature concludes that even inaction is agential and that intentionality does not determine complicity. However, bystanders are equally marked by their susceptibility or potential to be victimized by the violence they avoid. With particular reference to bystanders as subjects, S. Lochlann Jain's article (2004) on pedestrian injury and automobile design emphasizes that bystander is defined 'through a vulnerability to injury' (Jain 2004: 61). The collusion of actively avoiding and being susceptible to political violence, however, is shaped by specific forms of assessment, interpretation and tactical knowledge.

4 I argue that bystanders engage in a tactics of anticipation. Tactics, as elaborated from scholarship drawing on Michel de Certeau (1984), combine opportunity and subversion. In a political context subject to ongoing political instability, Henrik Vigh (2006) describes such practices in terms of 'social navigation': 'the tactical praxis of navigating networks and events within a social environment in motion' (129). Whereas Vigh's findings show how a particular tactical action of navigation is named through a terminology of resourcefulness (2006: 128-137), I suggest that Karachi residents did not use a distinct taxonomy to describe the practices of bystanders. Instead, their practices were emergent and conflicted, but informed by memories of previous experiences; I use the term anticipation to describe them. Rather than definitively transgressive, bystander tactics subvert unruly politics even as they are complicit in reproducing their own marginalization through a dense conjuncture of self-preservation, resilience and a lack of other options. The range and scope of tactics that avoid physical harm, recruitment and the social injuries of political affiliation/enmity are not equally available to all actors in every moment. For the proximate and immediate middle-class bystanders of political violence in Karachi, the activity of standing by is tactical in response to but also, 
significantly, in anticipation of their vulnerability. ${ }^{6}$ At the same time, however, their interpretations of anticipated possibilities rely on their participation precisely as bystanders, who abstain from, watch, wait out and thereby subject themselves to that which they understand as the violence of affiliation.

In Karachi's middle-class neighborhoods that are conspicuously considered the turf or contested turf of political parties, tactics of standing by took multiple forms. During violent scuffles, these involved taking refuge and waiting until the worst was over before tentatively emerging to resume more ordinary routines. Where parents perceived a diffuse threat, locating violence in recruitment and affiliation, they grappled with everyday attempts to ply or admonish their children to remain in surveillable spaces. Other, often younger and unmarried Karachi residents resolved to be fearless, and saw no paradox in their confident negotiation of variously politicized friendships and activities that elided any particular party affiliation.

\section{Traces}

6 The category of the bystander is not new. The existing literature on the MQM carries traces of such practices, mentioned in passing, that hint at possibilities beyond the activist party member and the victimized opponent. They suggest that it is eminently possible to work at remaining aloof while residing on party turf. In addition, they disabuse us of the easy slippages of unequivocal solidarity or paralyzing fear that triangulate either staunch and ubiquitous community support or helplessly terrorized subjugation from the basic facts of organized, violent territorial politics. For many Karachi residents living on party turf, everyday tactics hover somewhere in between the poles of victim and perpetrator.

7 In the scholarship on Karachi, few topics have enjoyed the attention of sustained analysis as have political party activists and their imbrications in violence. ${ }^{7}$ Most prominent among the parties examined is the MQM: the Muttahida Qaumi Movement or the United Nationalist Movement, which changed its name, but not its euphemistic acronym, in 1997 from the Muhajir Qaumi Movement or the Muhajir Nationalist Movement. Based in Karachi, the party was founded in 1984, building upon a student organization begun in 1978: the All Pakistan Muhajir Students Organization (APMSO). The founder of both groups, Altaf Hussain, continues to occupy the leadership of the MQM, albeit from selfimposed exile in London since 1992. Both party organizations mobilized a platform aimed expressly at a middle-class, Urdu-speaking constituency articulated as a new ethnicity, which identified Urdu speakers with the historical category of Partition-era migrants from India; Muhajirs. As a historical construction, the meanings of the term Muhajir and the implications of identifying with it have changed over time; 8 the formation of the MQM marks its mobilization as a political identity.

More so than any other party in Karachi, the MQM evokes urban violence. Although it is by no means the only party to do so, scholarship focuses primarily on this particular party's combination of identity politics and loosely organized excess. The MQM's formation, historical grievances, platform, leadership, organization, activist violence, subjugation by state security forces and those victimized by its activities have been the object of ongoing academic research. ${ }^{9}$ As such, the party's activities between 1985 and 1996, during the height of turf wars with political rivals and armed confrontations with the police, army and paramilitary Rangers, are well documented. Explanations for this 
attention invoke both the scale and alleged popularity of the MQM's notoriety for violence in conjunction with how it generated a new ethnicity. Less amply studied are the stories that disrupt the MQM's hegemonic purchase on political violence subversive of state interests. A number of issues elide this powerful narrative, notably the more recent history of a newly legitimized party (Baig 2008), or the ideologies structuring the violent activities of other parties (e.g. Haq 2007, Nichola Khan 2010c). Building on this growing attention to alleged peripheries of the 'proper object' of the political party, I focus on those Karachi residents who experienced party activities as bystanders. They may have been alternately sympathetic with or subjugated by the MQM, but neither worked for nor had any direct affiliation with the party, but nonetheless lived turf controlled, or contested by, the MQM. Paying closer attention to the accounts of bystanders can potentially re-frame how we think about modes of participatory politics, the forms of participation that make up what we acknowledge as political rather than depoliticized, and the place of Pakistanis who confound the dichotomy between victims and perpetrators of political violence.

9 The question of bystanders has become increasingly prominent as the incidence and orientation of political violence associated with the MQM has developed in new directions. Although scholars generally focus on its radicalization, the party trajectory has changed significantly since the late 1990s. Following the 29-month Operation CleanUp against alleged MQM activists between 1992 and 1994, a government-sanctioned attempt to suppress urban violence through a military occupation of the city, the MQM's radicalized side was gradually tempered by being incorporated and integrated into mainstream politics. In 1997, the MQM and the APMSO dropped the ethno-political term Muhajir from their names, replacing it with the term muttahida, meaning 'united,' in a bid to supposedly broaden their support base. As of the 2008 elections, the MQM led Karachi's city government, and represented the majority of the city constituencies in the Provincial and National Assemblies. In the late 2000s, however, renewed occurrences of violent confrontation between rival parties and target killings of Pathan business owners suggest a deliberate slippage into an ethnic register, widely presumed to be at the instigation of the MQM, in a way that explicitly draws on the memory of the party's violent activities in the 1980s and 1990s. More recently, a renewed spate of target killings escalated into an intensified broader confrontation in summer 2011, variously described as the result of turf-specific street enmities between the MQM and the PPP-allied party workers, ${ }^{10}$ infighting between MQM factions, or most conspicuously in the transnational news media, as a primarily ethnic conflict (see Supreme Court 2011).

\section{Turf}

10 Considering 'turf' raises the issues of a territorialized politics of location, where space and social relations intersect (Cox 1989). In tandem with official municipal boundaries and key landmarks mapped through experiences of everyday life, party turf in Karachi is heavily context-dependent. The regulatory status of land relative to state authorities plays a role in the history of access to and reliance on government services, thus affecting the positions of parties in a political landscape that may include and overlap with a host of relatively powerful stakeholders, such as a land mafias (Hasan 1999), prominent officials or local gangsters potentially trafficking in protection money, weapons or 
narcotics. The political territory of turf is also significantly qualified by the multiple and shifting possibilities of dominance by allied groups or contestation between enemies.

11 A growing scholarship emphasizes the established observation that political control focuses on local economic, bureaucratic and infrastructural neighborhood resources (notably Budhani et al. 2010, Gayer 2003, 2007). Informal squatter settlements not yet 'regularized' by the state, despite having their own dedicated counter at the offices of the Karachi city hall, form the basis for analyses of how community-based housing, struggles over land rights and limited infrastructure intersect at the site of ethnically motivated political animosity. This research highlights the 'rent-seeking behavior,' otherwise termed extortion or protection rackets, that provide the ongoing impetus for a specifically territorial scope for political control; an organization that 'owns' an area has secured the socially recognized privilege not only to occupy and symbolically claim that space, but also to solicit allegiance as well as funding. Conversely, contract enforcement and dispute arbitration also mark the commodified protection that characterizes a specifically territorially based politics of location (Budhani et al. 2010: 26, 27, Shah 2006). These forms of political control can be mobilized by gangs, ethnic community coalitions or political parties, depending on a neighborhood context. Effects of such practices in formalized, middle-class neighborhoods such as those discussed here include socially recognized public markers of affiliation, such as exclusive 'hangouts,' or social services reputed to overlap with party sympathies, such as hospital services in the heartland of party turf.

The spatially defined politics that coalesce around the notion of turf also invoke the shifting ground of contestations over territory, which complicate the issue of cohesive group solidarity, suggesting a certain flexibility in how affiliation, identification and enmity change over time. Party turf can be contested, fought over or eventually reconfigured through new sets of adversaries. Precisely because turf operates as a 'conspicuous interface between the formal and the informal' (Budhani et al. 2010: 25), it contains the possibilities of enforced dominance and thus also of unstable, necessarily volatile, contestation on a literal terrain of politics. The efficacy of these potentialities also shifts across moments of heightened tension, as well as in terms of everyday experience; political symbols and violence are more prominent and less avoidable in some moments rather than others. This changeability has itself been folded into social relations, conventional wisdom and regular routines in Karachi. ${ }^{11}$

\section{Unavoidable}

13 In January 2007, my arrival at a government college not far from Karachi University coincided with the agitated din of teachers and students reacting to a college rumble. Here, political animosities that were repressed by the presence of paramilitary Rangers at the nearby university campus found more explicit articulation. The key rivalry built on an historical enmity between the student wings of the standing rival parties, the Jamaati-Islami and the MQM. ${ }^{12}$ The metal gates at the college entrance and the highest points of the mid-rise building featured flags and graffiti tags of the rival groups, located in conspicuous relation to one another. The unusual proximity of rival markers signified an ongoing contestation over the college territory as political turf. 

indicated by the steel bars that had been fitted onto the women's side of the building, and belied by the carefree lounging of young men on the grass, the animated chatter of young women clustered in small groups, the regularity with which vans and private cars picked up or dropped off students, and the college's reputation for admitting only the most diligent and studious applicants. Attending such government colleges suggested students' inability to afford or be admitted to either public universities, or the array of much more costly privately operated institutions of higher learning. The reputation for a high quality of education at this particular college implied not only that most students were trying to get that best education they could within their means, but it also suggested that, relative to other colleges, student disaffection and politicization did not substantially unsettle the business of pedagogy. on a scale comparable to the more regular policing at universities. Instead, the administration relied on the cooperation of local police and the generational efficacy of intimidation, as well as the contingent possibility of interpellating normative cultural values of heeding or respecting elders, teachers and figures of authority. As Oskar Verkaaik $(1994,2004,2009)$ has repeatedly shown, reversing or transgressing normative hierarchical structures, especially in terms of generational authority, is a key feature of what makes street politics attractive to young men in Karachi. A college rumble, however, produces bystanders as well as victims and perpetrators. Vectors of participation are informed by the situated locations, not only of those who engage in the performance of aggression, but also by those who retreat from, give way to and make space for violent action. This is exactly why it is imperative to pay sustained attention to how bystanders enable the political violence precisely in the moments that they seek to avoid vulnerability.

I had visited the college on a number of perfectly uneventful occasions. A teacher offered to introduce me to her class of male students and we arranged to meet. Our meeting on the girls' side of the gender-segregated campus had barely begun when it was disrupted by the male voice of a college employee yelling 'the atmosphere has gone bad!'(mahaul kharab ho gaya hai!). This provoked no hesitation among the women students. In an immediate stream of neatly pressed beige student uniforms, over a hundred young women flowed into the gated interior corridor that was separated from the courtyard by metal bars. A few screamed and some pushed, rushing into the hallway before the heavy gates were padlocked, which effectively locked in the young women and administrators while the male students, lounging on their half of the gender-segregated grounds, were left to fend for themselves. The range of reactions and recognitions did not convey surprise. The specific activities of getting out of the way had the clear tenor of familiarity. The entire women's section had been warned, relocated and secured in a safe inside space in less than a minute. No one had fumbled to find the lock. It seemed that I had been the only one confused or uncertain about what was going on. Many women students went directly into the classroom interiors, but a sparse crowd gazed through the bars and across the campus, trying to make out what was happening. I was instantly shuttled through to an adjacent office, where female teachers and staff, marked by the privilege of not being in uniform, took refuge. an onslaught of fragmentary details through the clamor of staff comments. A scuffle was

South Asia Multidisciplinary Academic Journal, 5 | 2011 
happening right at the gate at the entry to the college, which foiled the usual strategy of closing the main gates to contain or cut off the disturbances. The teacher I had come to meet turned to me and asked whether I had noticed anything as I had come in. I thought about it and remembered a silence unusual only in retrospect, however, as young men in college uniforms and in $\mathrm{t}$-shirts looked at each other, seemingly haphazardly clustered just inside and just outside the main gates. With every evidence of being unperturbed, the teacher sat demurely with me on a wood frame sofa and tried to make polite small talk while on the desk adjacent to us the principal, an outspoken middle-aged woman, alternately yelled at and pleaded with the police on the phone. She admonished them for not coming when she had called ten minutes earlier, when staff had first gotten wind of a potential escalation. This would have been several minutes before I had arrived at the college, suggesting that I had walked through the main gates, the epicenter of the conflict, just as teachers had begun watching for signs of escalation. Meanwhile, about thirty male staff members delivered sporadic reports about the logistical difficulty of clamping down of a violent scuffle at the threshold of the main gates, about skinny boys bearing cricket bats as weapons, about bleeding wounds after only ten minutes, and about memories of previous conflicts where boys had slashed each other with the jagged ends of neon tube lights taken from classroom ceilings.

Memories of past experiences informed anticipatory tactics, scripting them into actions so regularized that they had become routine. Call the police. Berate the police. Warn the students. Padlock the women's section. Try to close the main gates. Watch for blood or other forms of escalation. Wait in a place of refuge for the violence to subside or the police to intervene. Tentatively emerge to reclaim spaces where the violence occurred and resume more regular, less extraordinary, routines.

The teacher's small talk fizzled quickly. She asserted that this sort of things did not happen often, and gave me three versions of what happened, modifying the account in relation to common motifs of criminality, ethnic conflict and political animosities as she went along. Initially, she maintained, there were just ten or twelve boys involved; they were bad apples. A few moments later, she narrated the rumors of an ethnic clash between Punjabis and Pathans. Ultimately, however, she explained that there were people that came from the outside to create trouble among our students. By this, I understood that she meant that party workers and recruiters who were not students helped to instigate and sustain political animosities on a college campus where, despite the overt symbols that marked it as a contested party turf, any form of student organization had been officially banned for twenty-three years. In her ongoing modification of an explanatory narrative, the teacher offered me a succession of predictably familiar formulae, in effect testing how susceptible I might be to leaning towards stories of individual responsibility, naturalized ethnic animosity, or the "hidden hand' of organized politics. That the teacher referred to political parties rather than to any other form of affiliation was implicit in her clear references to recent newspaper debates about banned student groups and allegedly external provocateurs, as well as the painted colors and graffiti on the campus buildings extolling the rival student wings of the MQM and the Jamaat-i-Islami.

In using a common set of euphemisms referring to party workers, she asserted that the students were not involved, but immediately backtracked, admitting 'maybe a few students, but we can't do anything to them.' This oblique reference amplified the explanation that remained unsaid, if clear in many other stories and accounts: the 
inability of teachers and staff to reprimand or otherwise engage such students rested on the fear of anticipated repercussions for themselves and their families, in terms of threats and intimidation. In effect, the anticipation of consequences was enough to keep teachers and staff from taking their chances in trying to assert their authority. These tactics anticipated not only scuffles to avoid, but also the potential effects of direct intervention for their families and situations at the workplace. It was, thus, anticipation in multiple degrees. I had met others who appeared less concerned with the palpable ramifications of harassment, but perhaps they had had alternative resources that permitted them to consider themselves fearlessly immune. The teachers and staff at this college evidently did not share such sentiments. Not one dared to attempt asserting their authority against the confrontation at the gate. Instead, they took refuge inside and waited for the police. 'So,' the teacher concluded, gesturing to the situation of barricaded domestic confinement which formed the context for our conversation, 'we get terrorized like this.' Her use of the plural 'we' indicated that to attempt to avoid the entanglements of party politics, but nonetheless become embroiled in its moments of danger, hailed a shared experience that merited a collective nomination. I suggest that naming this collective experience indicates a shared sensibility, points towards a broader sociality, and alludes to a modality of participation constituted by the tactics of being a bystander to politicized violence. Eventually, I was escorted through the school gate post-lockdown, where police vehicles were stationed on either side of the campus grounds, only to find that a number of the few cars outside had suffered collateral damage, pelted by rocks, and to hear accounts of the sudden escalation of tension into violence that had scattered bystanders to take hurried cover.

The teacher used the English term 'terrorized' to describe the anxious group of teachers, students and staff who watched and waited for the rumble to be over from within a refuge of walls and metal bars. Her usage effected a distinction between those who engaged in politicized violence and those who did not. In tandem with their subjection, precisely through the tactics of avoiding involvement and thus minimizing their susceptibility to injury, the bystanders worked against violent confrontations by not participating in them. This was about more than fear; it was about the resilience of waiting and resolutely reclaiming spaces that had, at one time or another, been sites of violence. As such, standing by entailed specific activities and practices of anticipation, both during instances of heightened animosity as well as during the times of suggestion and potentiality, where the possibility of benign or threatening situations was continually assessed and interpreted.

Anticipation is, by its very definition, ensconced in contingency, hypotheses and 'best guesses' based on past experiences and available information. For all that, it is nonetheless something that Karachi residents do to make their lives both bearable and sustainable in a situation of variable and volatile levels of political violence. Such practices of standing by simultaneously reject while conceding space to, and thus perpetuating, politicized aggression. As a result, attempting to avoid vulnerability is neither intentionally nor effectively transgressive. While it subverts party claims to representative identity politics by drawing explicit attention to the persons and tactics that violent political mobilization excludes, it is also complicit in reproducing the subjection and marginalization of a majority, whose main concern of self-preservation indicates resilience as well as a lack of other feasible options. 
24 As the incident at the college demonstrates, anticipatory practices are not equally open to everyone in the same ways. Whereas female students were the most physically distant from the center of the conflict, but were also able to retreat into an enclosed and secure part of the building, male students were left by the administration to fend for themselves, to improvise their own refuge. In addition, teachers and administrative staff had access to even more insulated interiors; to rooms with locks and supplemental sets of bars. This contrasted markedly with the pedestrians, cars and drivers who had been just outside the gates when the scuffle began. Caught in the open area of the college driveway, they dove for cover behind the few parked vehicles as the enemy groups first pelted one another with rocks, and then the cars behind which bystanders were cowering. These modes of evasion demonstrate a set of differentiated practices that characterize the ongoing condition of the bystander in a context that is regularly, if not in every moment, suffused by violence.

The principal form of vulnerability from which students, teachers, staff and drivers withdrew was one of physical harm. At least, staying out of harm's way was what they had in common. For students, however, this physical threat was compounded by the potential malevolence of affiliation; solidarity with one side not only strengthened ties of association, it also generated new categories of enmity with a host of rival organizations. As I repeatedly heard, those who do not retreat must be protected by and affiliated with someone, which meant that they must also have been someone else's enemy. Conversely, the hesitation of teachers and staff to test their authority against volatile and wellprotected students indicated their awareness of possible retribution, and the fragility of culturally normative hierarchy in the face of violent intimidation. The teacher had suggested as much in her comment that evoked the conventional wisdom of fixed exam results and coerced grade inflation, in addition to violent outbreaks: 'We can't do anything to them.' Thus, the tactics that avoided physical harm also anticipated social injuries, for students, of direct involvement in an economy of affiliation, and for teachers, of potentially losing the symbolic force of their authority.

\section{Parents}

Analogous to the authority figures of teachers and staff at the college, who worked to protect students by shuttling some of them into an interior refuge, parents also acted as bystanders. The parents I spoke to resided on party turf, but strove to keep their children from becoming involved in party politics. For them, the animosity that escalated into the college rumble was rendered much more diffuse; they emphasized the foundational violence of affiliation. As such, the protracted threat was not conflict itself, but the tantalizingly benign fabric of friendship, leisure and admiration that promised a palliative to unemployment, frustration and vulnerability. Parental anxiety was about recruitment and the presumed irreversibility of this particular political affiliation. However, neither all adults nor all young people shared these worries. Some seemed confident in their capacity to negotiate and navigate any set of pitfalls, whereas others were convinced that fear and the politics of enmity belonged to an antiquated economy of affiliation. Their confidence did not exclude the anxiety of their parents or peers, who alternately worried and goaded them into different forms of prudence.

Parents used a host of tactics to navigate and manage the rhythms of everyday party politics in their lives. In particular, they shared accounts of how they struggled to keep 
their children safe, to keep their sons from being recruited into party politics, to protect them. I focus on the narratives of two parents who lived in Nazimabad, a neighborhood known as a historically important political turf of the MQM, as well as one parent who had moved away from Nazimabad during the turf wars of the late 1980s, and now resided in Faisal Colony, a part of New Karachi, on a street that was part of the contested terrain between the MQM and the Jamaat-i-Islami. All these parents invoked the MQM rather than any other party, typically using oblique references they and many other residents considered unequivocally obvious. Investigating their narratives presents an important complement to extensive studies of the political party as an object: how the MQM is imagined by the scores who are not party workers in its own 'heartland.'

Nazimabad was established in the 1950s, one of several neighborhoods planned on a government initiative to house the hundreds of thousands of refugee migrants from India. It is located in the western half of Karachi, and consists of five major areas, composed largely of row housing. Although a number of Muhajir-dominated parties operated there, Nazimabad continued to be considered the turf of the MQM. Party flags in the telltale colors of red, green and white lined streets and roundabouts. MQM colors were painted around lampposts and on fountains. Neighborhood parks were named for martyrs, that is, party workers killed during the government military operation that clamped down on the city for 29 months between 1992 and 1994. Immediately adjacent to the 'no-go areas' declared off-limits by police and government security personnel, Nazimabad was affected by curfews and street violence during the infamous turf wars of the period. The time I had spent there in 2006 and 2007 had been comparatively peaceful, where MQM representatives had dominated Karachi's local government. Regular, if variable, levels of violence persisted in the area, as well as in several other proximate neighborhoods where the MQM had been particularly active a dozen years before. Nonetheless, Nazimabad can be considered an aftermath (Das 2007). ${ }^{13}$ This neighborhood of over sixty thousand residents made palpable not only the memories of a protracted period of urban unrest, but also a host of other social effects: droves of residents moving out in the late 1980s, new residents moving in beginning in the late 1990s, parks where families could picnic and where women could stroll with their friends in the evenings. The long-standing Nazimabad residents I knew were the ones who had stayed behind, whether out of conviction or compulsion. Several claimed that they were some of the very few left on their blocks, that everyone else had moved away a decade earlier, and that they did not know their neighbors anymore.

Conversely, Faisal Colony was part of the larger area of New Karachi, initially established as part of the Greater Karachi Resettlement Plan in the late 1950s, a failed government initiative and basically 'an eviction drive' (Budhani et al. 2010: 20), to resettle poor refugee migrants living in squatter settlements to areas $20 \mathrm{~km}$ away from the city center. ${ }^{14}$ The industrial expansion that was supposed to accompany the residential development, and provide employment for those who moved there, never materialized. As a result, 'half' of the resettled residents returned to living in the inner city to be closer to their workplaces (Hasan in Zaidi 1997: 3286), many poor families sold their plots to speculators who re-sold the land to middle-income buyers, and the project continued to face financial issues several decades later due to the difficulty in collecting the dues intended to recover government investment (Zaidi 1997: 3286). According to the 1998 census, Faisal Colony was estimated to house approximately sixty thousand residents. ${ }^{15}$ 

stories about shots fired or dead bodies found in the neighborhood were common. During that time, Jamaat-i-Islami representatives ran the local government of the area, but were consistently challenged by MQM activists. ${ }^{16}$ The residents of Faisal Colony were largely Muhajirs, although people from diverse ethnic, linguistic and religious groups also lived there. The residential roads were narrow, and the homes combined small apartment buildings, row housing and compact bungalows. Homes were conspicuously walled and gated, although space inside them was at a premium. Although motorcycles and vans transporting schoolchildren were common, I did not see many private cars beside the one I was using. This was a precariously middle-class neighborhood.

31 attracted to party politics, and explained how they, as parents, tried to counter the allure of affiliation. Not only did a party offer the intimacy of allies and supporters, which might play out in contexts ranging from employment to hospital services to targeted intimidation, but it also offered monetary compensation to activists. Of all the parties, I was told, the MQM paid out the highest allowance and had the most well-paid workers. Where unemployment was a common complaint, party politics was bound up in a political economy of social distinction and disposable income. The parents I spoke to recognized that the slippage between a party worker's allowance, leisure spending and powerful friends held some attraction for their children. spaces, also enlisting the influence of friends, neighbors or local elders to persuade their sons to understand the necessity of a particular course of action. Persuasion and surveillance made up the tactics they used to anticipate and through which they hoped to prevent recruitment. Young men were dangerously vulnerable precisely because they were culturally understood to be more independent, and less subject to parental supervision, than young women. Parental oversight thus relied upon enforcing the normative hierarchies of generational authority, but also upon the emotionally intimate forms of persuasion, that politicized sons were thought to be immune to (Verkaaik 1994, 2004). These parents struggled with the knowledge that their influence could only be indirect, that it could only anticipate, but not definitively foreclose, that their children successfully avoided potential threats. Both mothers and fathers explained the means and impossibilities of controlling the movements of adult sons.

33 Samina Baji was an Urdu-speaking housewife and mother of five in her mid-forties. Like most of the people I knew, her parents and grandparents had migrated to Pakistan from Uttar Pradesh as Muhajirs. Samina Baji had resided in different parts of Nazimabad throughout her life. She described barely going outside when she first moved in with her husband's family in the mid-1980s, during the years when 'the atmosphere was bad,' and they had regularly heard gunfire through the front door. Twenty years later her family had moved to the same block she had lived on as a child, but most of the old neighbors had moved away in the interim.

She had two grown sons, and spoke of the one that had found work abroad, in the United Arab Emirates, with visible relief. The other son was currently unemployed. She hesitated for a few moments before describing the potential dangers that ultimately outweighed the benefits of being recruited as a party worker. In an agitated tone that combined sympathy and anxiety, Samina Baji told me that if a son joined any political party, then everything was futile, useless (bekar). She explained that they would never be able to

South Asia Multidisciplinary Academic Journal, 5 | 2011 
leave that party and if they tried, they would probably be killed. And the poor things, she said, they feel frustrated and have no contacts or no money. At least from the party, they get some cash and some importance. Maybe the party will help them to get a job. But, she insisted, it is so dangerous and a disaster for the family. Samina Baji outlined her objective and alluded to meager tactics she had used to try to anticipate and foreclose the possibility of recruitment. Acknowledging that her attempts to control her sons were ineffectual, but still turned out well in the end, she pointed to the radical contingency that rendered anticipatory practice an ongoing, flawed if hopeful, anxiety-fueled project. The biggest thing, Samina Baji explained, is to keep your boys from joining a party-and you can yell at them and keep them inside like girls, but they are not girls. She asserted that by the grace of Allah her boys had not joined parties. That they had not despite residing in an MQM stronghold remained the unspoken context of her narrative, and from the breathless way that Samina Baji had conveyed relief as she ended the conversation, this result had evidently not been a foregone conclusion.

Samina Baji had hoped to keep her sons from being recruited by political parties, although she knew that their frustration and difficulties in finding respectable employment made party membership seem attractive. She focused, however, on the trade-off between protective affiliation and family solidarity. Her own tactics of anticipation had been, by her own admission, fueled by hope and anxiety, and had not been deciding factors in the outcome. Despite her acknowledgement of forces beyond her control, Samina Baji nonetheless tried to engage the parental modes of authority through which she desperately wanted to be persuasive.

Omer Sahib was an entrepreneur who lived in Nazimabad and operated a small real estate business. His family had also migrated from Uttar Pradesh at Partition and had lived in the neighborhood since the mid-1950s. He used specific tactics to anticipate the potential violence of party involvement, and described how he had kept his sons from being recruited into political parties by encouraging them to pursue hobbies indoors. He told me that the key to keeping kids away from political organizations was to keep them off the street. By this, he explained that he meant keeping young men inside the home rather than have them sitting on a roadside curb or in a local hangout, where they would be vulnerable to recruitment through association and informal friendship with members of organizations (tanzimi log). Omer Sahib described his strategy as giving his sons things that they could use inside, buying these things and thus investing in them, such as a television or videogames. Omer Sahib framed consumer desires as a distraction from, as well as compensation for, the social and affective networks that political involvement offered. He described how one of his sons had been interested in the game of carrom board, generally played on a large wooden board in local gaming dens, which were perceived as dangerous because of the presence of gambling and unsavory characters. Omer Sahib promptly bought his son his own board for the exorbitant price of about one hundred dollars (equivalent to 5000 rupees in 2007). He described the process as a reflexively anticipatory, deliberate and multilayered performance, where he had taken his son to the bazaar and asked him which carrom board he wanted. Omer Sahib elaborated that his buying the board, and pulling out that much money at the bazaar, had produced the effect of being a 'big man' or important person, at least in the eyes of his son. Secondly, he noted, it showed that he spent or invested in keeping his kids sheltered and out of undesirable places. Finally, Omer Sahib said that buying the carrom board had been a way to gain the trust of his son, as an indulgent parent, which would bind the boy 
even more closely to his father and family. Quite literally, the father explained that his son would probably bring his friends to play carrom in his home; that is, in a safe and controlled surveillable place. He thus orchestrated an intricate situation that anticipated the allure of leisure activities while cultivating the figure of the indulgent parent as an effective patron.

Whereas Samina Baji narrated specifically domestic confinement as a key modality of avoiding what she described as the futility of party membership, Omer Sahib extended these tactics to a more generalized distancing from unsupervised, and thus potentially unruly, locations. To evade such dangers, Omer Sahib performatively fostered an indulgent relationship with his sons, indexed through his willingness to strategically invest monetary resources so as to cultivate a particular form of intimacy that doubles as protective surveillance. In countering party involvement with structured activities requiring conspicuous consumption, he appeals explicitly to his sons' desires (khwaishat) in order to connect them to family resources, rather than a potentially volatile exterior space.

For Omer Sahib, vulnerability to party recruitment was importantly linked to informal acquaintances made in unsupervised spaces. His tactics, therefore, were to attempt to compete with the attractions of such spaces by channeling leisure activities into a domestic location. He explained how his efforts had been successful, but this had not made them any more than contingent and hopeful at the outset. Like Samina Baji, his alternative to party recruitment depended on reinforcing family solidarity and the relationships within the household.

Allegedly controlled spaces did not always ensure protection, however. Schools posed a problem for the idiom of protection and supervision, because time in the schoolyard, commuting, or doing homework with classmates was not structured by teachers. In such cases, parents knew that their tactics were limited to anticipation; assurances were contingent and sustaining the position of a bystander meant opting to remain vulnerable and susceptible to injury. That this was a conflicted and difficult stance to maintain was acutely felt by Anjum Baji, a housewife and mother of five children. She lived with her husband and mother-in-law in Faisal Colony, where the Jamaat-i-Islami and the MQM were actively struggling for control of the neighborhood and its local government. This situation was especially salient for her family, because Anjum Baji's husband was a member of the Jamaat-i-Islami.

As she told me about young MQM workers who harassed local residents, her narrative slipped into a harrowing discussion about how her fifteen-year-old son faced party animosity in the schoolyard. Sons of MQM workers had begun taunting him because his father worked for the Jamaat-i-Islami. This account suggests that the political affiliation of parents is often passed onto children by association. Anjum Baji explained that schoolboys were being recruited, plied with small rewards and motorcycle rides, and encouraged to demonstrate their loyalty by physically assaulting enemies constituted through the impetus to defend the honor of their fathers. Voice strained and eyes watering, she described how she had encouraged her son to avoid such activities, to remain aloof, and to try to be a bystander. Her tactics, which her tears acknowledged as limited and removed from the schoolyard, persuaded him to rely on piety and virtuous conduct: I have explained to him, son, just be a good Muslim and Allah will keep you safe. Don't look, she said, don't respond, just be a good Muslim, I have explained this to him. To advise the use of piety, rather than violence or affiliation, as a form of protection drew on 
the religiously informed platform of the Jamaat-i-Islami, but Anjum Baji explicitly exhorted her son to equate effective piety with the position of the bystander. The active component of this stance included not looking or responding to the taunts of his peers; this was implicitly part of what it meant to be a good, respectable, middle-class Muslim boy in a schoolyard. Anjum Baji's fears clearly anticipated her son potentially being beaten, killed or otherwise bound up in the economy of street battles and threats that political activity in Karachi implied. By telling her son to just be a good Muslim, Anjum Baji exhorted him to ignore the provocations of his classmates and focus on piety as a sufficient means for maintaining virtue and navigating the pitfalls of the schoolyard. The implication, through his mother's anxiety, was that if he were a good Muslim, he could successfully avoid messy economies of affiliation, intimidation and violence; Allah would protect him through an alternate, if no less contingent, tactics of anticipation.

Whereas Samina Baji and Omer Sahib maintained that avoiding the vulnerabilities of party recruitment depended on spatial control and confinement, Anjum Baji attempted to urge her son to pious moral conduct in order to evade provocation. In imploring him not to look and not to respond to taunts, she pleaded with him not to enact a definitive affiliation that would symbolically justify a potentially violent enmity. Her advice to her son pre-empted recruitment itself, as well as physical harm; its most immediate concern was to avoid actions that could be interpreted as affiliation, and extrapolated into opposition by dangerous rivals. There was no guarantee, of course, that her son would heed his mother's words or evade politicized bullying, and I believe that this knowledge is what brought Anjum Baji to tears. As a mother, she could only try to convince him that he had a choice in deciding whether or not to get involved.

The efforts and anxieties of these parents demonstrate a mode of evading involvement in political organizations, and thus rejecting violence through the position of the bystander, on behalf of their children. They suggest a generational imaginary of avoiding party membership, through a tactics that anticipates that the dangers of affiliation are ultimately potentially far more treacherous than the contingent and carefully hopeful vulnerability of the bystander: retreating, waiting, trying not to look, trying not to respond. How do you keep your children from joining a party? How do you keep your sons safe? According to Samina Baji and Omer Sahib, keep them inside, at home, off the streets. Anjum Baji suffered through the anxiety of knowing that she could not help, control or protect her son in the schoolyard. These parents' efforts were not oriented towards confronting, containing or opposing potentially violent political organizing. Instead, they wanted their children to avoid such situations, and subscribe instead to the cultural and affective primacy of kinship solidarity. Although their priorities set up a contest between mobilization and the order of familial hierarchy, as has been explored in terms of generational tension (e.g. Verkaaik 1994, 2004), directly anticipated in these parents' narratives is the possibility of physical harm brought on by the enmities that are part and parcel of affiliation with, and protection by, a powerful organization. The threat is thus in the inflexibility that affiliation brings.

Conversely, however, just as in the retreat of bystanders in the college rumble, these tactics ultimately make space for the intimidating danger of political affiliation, reinforcing its power, and perpetuating its efficacy. The options offered involve a withdrawal into domestic interiors, and a moral ground to refuse provocation. The subversion enacted here is complicit, and enacts subjection even as it feels like a form of resistance. For all that may seem that anticipatory practices are described as elective, for 
the reader as well as for the Karachi residents I have described until now, such tactics are experienced as compulsion.

Parents' accounts show us that anxiety, fear and an idiom of protecting and supervising young men are bound up in the affective, extra-institutional practices and imaginaries that are conjoined with political institutions in Karachi. However, not all residents of party turf are quite so anxious about the potential malevolence of proximity to political affiliation. Some are also fearless, defiant and confident in their own abilities to navigate and negotiate a range of situations.

\section{Unafraid}

A particular sentiment was generally repeated by those who were old enough to remember the fear (khauf) that had pervaded the 1980s and 1990s: 'Nowadays, people don't heed hooliganism' (ajkal log badmashi nahin mante). The verb for acquiescence-manna -was the same one used to describe relations between subordinates and authorities; children listening to or obeying parents and teachers, or young people doing what elders told them to. The negation of this compliance indicated fearlessness, recklessness and an indignant refusal to tolerate the paranoid expectation of threats and blackmail. Nonetheless, even for those Karachi residents who confidently sustained relationships with a host of variously politically affiliated contacts and friends, conversations about parties were abruptly cut off if someone with unknown sympathies entered a room, and the allusions to fearlessness were couched in quiet voices and oblique references-those who spoke loudly and frankly were either surrounded by friends, protected by affiliation, or considered simultaneously careless, brave and naïve.

In contrast to the bystanders whose tactics anticipated proximity and familiarity with party affiliates as potentially dangerous, other, often younger, Karachi residents confidently sustained relationships with active members of rival parties (Baig 2008: xvixix, Nichola Khan 2010a: 131-133), ignored the pressure to definitively affiliate with any group, or otherwise disregarded the anxiety that their own vulnerability might engender. While their approach did not instrumentalize political affiliation as a social field commodified protection (Shah 2006), its navigations were pointedly-if only, according to their elders, temporarily-fearless. In contrast to the suggestion by Pradeep Jeganathan (2000) that restraint and fearlessness are opposed in relation to violence, these bystanders demonstrate a stance that is fearless precisely because it holds onto restraint. As such, their tactics of anticipation further elaborate the practices of active bystanders that awkwardly combine subjection, subversion and complicity.

Some young people offered a counter-narrative to their parents' concerns; they avoided street politics and everyday urban unrest through defiance rather than out of fear. One example was confidently brandished by Bushra, an unmarried Urdu-speaking young woman in her early twenties. She lived in what I was told was the best lane in the neighborhood; young people would travel there from other sectors in Nazimabad, just to comfortably spend time with friends in this lane. Its reputation designated it as a haven where it was possible to avoid party politics. As her mother looked on with concern, Bushra asserted the difference between this lane and the others in Nazimabad: we go outside, she said. She described those parents who did not let their children out because of fear (bacchon ko nikalna nahin dete khauf ke waje se). The solution, she said, was simple: don't be scared, get rid of the fear, finish it-go outside (mat darna, khauf khatam karna- 
bahar nikalna). Bushra joked about how neighbors and young people would linger on doorsteps in the evenings, watching each other and gossiping cheerfully. As she spoke, her mother wrung her hands and knit her brow.

A parent's fear and a child's defiance existed in relation to each other, both formulating differential tactics for an everyday life that avoided party politics. Bushra explained that small blockades at either end of the lane served as a barrier, preventing access by boys on motorcycles commonly associated with the potential for easy, inexpensive mobility. This helped to prevent muggings and mobile phone theft, she said. The barriers had been erected when a recently elected local politician, who lived on that block, had his cellular phone stolen at gunpoint. The event implied that younger party workers had inadvertently mugged a senior MQM party member in the heartland of their mutual turf. The prominent neighbor acted as a buffer for Bushra's fearlessness by establishing the material conditions facilitating the easy leisure of residents. Not everyone on the block perceived these conditions as inviting, however. Bushra's mother narrated that the new people who had moved into the neighborhood since the late 1990s kept to themselves and kept their children indoors; we hardly know what they look like, she exclaimed. Evidence of this novel anonymity was cited through an incident where it had taken three days to identify the victim of a nearby accident; longstanding residents had not recognized that he lived on their block.

The fact that Bushra so comfortably defied the vulnerability to violence, mugging or recruitment was made possible by an influential party-affiliated neighbor. Thus, her fearlessness was sustained by the politics of MQM turf, even as she and several other young people maintained that the relative safety of the lane depended on the lack of pressure to join the party. Bushra's resolution to go outside and be unafraid was a highly contingent subversion; it was anchored in the spatial circumstances of protective affiliation. More starkly than in the examples of the college rumble or the narratives of parents, Bushra's tactics were shaped by what party-affiliated actors allowed to happen in the spaces they ostensibly controlled.

Several young men seemed to successfully navigate amongst party networks without resorting to any bottom line of official affiliation. Their friends had various levels of involvement in different parties, while they managed to remain aloof. One young man who was just finishing high school confided his anxieties; he had heard that boys were advised to join a political party upon entering university, which was supposed to ensure a protective network, as well as access to the social capital that could provide access to resources. His worries did not seem to correspond, however, to the experiences of many of the students I knew. Another acquaintance, a university student, would occasionally mention acquaintances or rallies that he had attended, often of historically oppositional parties. Several others mentioned friends that were active in campus politics, although they were not involved themselves. The pressure to become an official member of a party, they told me, was not as strong as it had been a decade earlier. Joining a party, they said, was no longer necessary. What do we make of these spaces of navigating avoidance, these people who mediate between interests and affiliations whose stakes were frequently described in absolute terms? I maintain that their engagements are more than mere retreat; they constitute the active tactics of bystanders, albeit ones who seem less perturbed about potential dangers and more confident in their own capacities of 'social navigation' (Vigh 2006). 
51 An Urdu-speaking university student in his twenties, Farid Bhai narrated the way he had avoided recruitment. He sustained relationships with friends that had a range of political affiliations. He told me that some of his closest friends were key members in the student wing of the Jamaat-i-Islami or the MQM. Despite fraternizing with active members of enemy organizations on the same campus, Farid Bhai avoided becoming officially affiliated with any political party. He had attended the rallies of historically oppositional parties, and had occasionally mentioned his exhilaration in a crowd of MQM supporters or his sympathy with the political platform of the Jamaat-i-Islaami. I suspected a generational and historical component that made his conduct feasible when he mentioned that the elder brothers of several of his friends were involved in some level of political organizing, as either workers or administrators, although the friends considered themselves unaffiliated. Perhaps time had made it easier for social networks not to be conflated with affiliation, but perhaps this was an orientation that was possible for the imaginary of a younger generation; parents and teachers used tropes of friendship and seduction to refer to the slippery slope of recruitment.

52 He told me that an old family friend had risen to a prominent position in the MQM. At sixteen, Farid Bhai had been offered a well-paid clerical position in the MQM's administration, which he flatly refused. Fear or anxiety never came up in his narrative, although the dramatic description of 'flatly refusing' party employment suggested Farid Bhai's awareness that his actions were daring, and could easily have been interpreted as both insolence and bravery. Rejecting the offered position had not prompted him to modify his relationship with party members, however. He asserted that it had not been a problem to remain on good terms with them afterward. Farid Bhai, and several other young men or middle-aged women like him, comfortably maintained an amazingly varied array of friends and acquaintances who had an equally dizzying array of bureaucratic, economic and political affiliations. None of them were invested in explicitly opposing, or working against, the structures of affiliation they navigated. As such, they did not constitute their actions as resistance; instead, their tactics were simultaneously subversive and complicit, but accompanied by an affect of wily, slippery mischief rather than the anxious fear so prominent in the examples of the college rumble and parents' narratives. Farid Bhai and others like him most convincingly articulate their tactics as elective, although the ability to make such choices depends equally on the ability to negotiate or successfully wriggle one's way out of unfavorable situations. In mobilizing social capital, they worked at the interstices of the organizations and institutions that shaped Karachi's political terrain.

53 This did not mean, however, that Farid Bhai was not cautious, although I must note that he was most prudent when his mother was the most adamantly insistent about it. Nonetheless, his particular combination of a pious 'reputation,' a knowledgeable articulate demeanor, as well as his informal and non-party community involvement may have contributed to his effective navigation of an economy of affiliation. Although fearlessness was an explicit aspect of Farid Bhai's tactics, his longstanding personal relationship with the prominent MQM party member configured, not only the particularly generous offer of recruitment, but the way his 'flat' refusal was benignly received. I knew of another situation in which the recruitee had locked himself in his home for three days until the recruiters had stopped asking about him. Some of this difference may be anchored in personal competencies, ${ }^{17}$ and some in the clerical position 
Farid Bhai was being offered, but it appeared to be structured by a profoundly situated imaginary of the political in urban Pakistan.

The facts of the tactics employed by Karachi residents such as Bushra and Farid Bhai are not nearly as important as what we lose if we disregard their experiences. People who anticipated that fear, anxiety and definitive political affiliation were imperative to avoid or navigate rather than to join demonstrate that political mobilizations in the violent and territorialized history of Karachi constitute bystanders as well as activists and victims. Considering these alternate stances prompts us to confront how exactly it is possible for subjection and subversion to be aligned, and for practices of non-affiliation to perpetuate, by ceding to or making space for, the particular forms of political volatility that they sought to evade.

\section{Conclusion}

The tactics of middle-class bystanders in Karachi associate political affiliation with the multiple vulnerabilities of physical harm, recruitment and social injuries that both undermine culturally normative hierarchy and invite specific oppositional enmities. As a highly contingent set of subversions, such tactics are complicit in their own subjection as they make space for the very dangers of political violence they avoid. Just as depoliticization and voter apathy are constitutive of ostensibly functional democracies ( e.g. Putnam 2000), the practices of bystanders who do not mobilize are important aspects of Karachi's political landscape. The violence of turf politics has been described as a key feature of processes of democratization in Karachi, envisioned through ongoing contestation and negotiation between and amongst local stakeholders and state actors (Baig 2008, Gayer 2003, 2004, 2007, Haq 1995, Hussain 1990, Nichola Khan 2010b, Naqvi 2006, Shaheed 1990, Verkaaik 1994, 2004). The tactical action of those millions subjected to its effects demonstrates how everyday politics shape people's lives, and in turn, how their tactics both enable and subvert political contexts.

Bystanders enact a relation to the political and, more importantly, a mode of participation that corresponds neither to victims nor perpetrators. In Karachi, to sustain the position of a bystander involves an active set of practices. Not quite a movement, it is nonetheless eminently social. These tactics fall short of an identity, yet they are a key and regularly re-iterated feature of Karachi's everyday life. The question is not how to motivate this potential group into a solidarity we already recognize, but how we alter our perspective in order to make palpable the ambivalent work that their emergence has already done.

\section{BIBLIOGRAPHY}

Ahmed, Feroz (1998) Ethnicity and Politics in Pakistan, Karachi: Oxford University Press. 
Ansari, Sarah (2005) Life after Partition: Migration, Community and Strife in Sindh 1947-1962, Karachi: Oxford University Press.

Baig, Noman (2008) From Mohallah to Mainstream: The MQM's Transformation from an Ethnic to a Catch-All Party, M.A. thesis, Department of Political Science, University of Victoria, Canada.

Berlant, Lauren (1997) The Queen of America Goes to Washington City: Essays on Sex and Citizenship, Durham: Duke University Press.

Berlant, Lauren (2008) The Female Complaint: The Unfinished Business of Sentimentality in American Culture, Durham: Duke University Press.

Budhani, Azmat Ali; Gazdar, Haris; Ahmed Kaker Sobia; Mallah, Hussain Bux (2010) ‘The Open City: Social Networks and Violence in Karachi', Crisis States Research Centre Working Papers Series 2, 70, Crisis States Research Centre, London School of Economics and Political Science.

Butler, Judith (1997) The Psychic Life of Power: Theories in Subjection, Stanford: Stanford University Press.

Chaudhry, Lubna Nazir (2004) 'Reconstituting Selves in the Karachi Conflict: Mohajir Women Survivors and Structural Violence', Cultural Dynamics, 16(2-3), pp. 259-290.

Chaudhry, Lubna Nazir; Bertram, Corrine (2009) 'Narrating Trauma and Reconstruction in PostConflict Karachi: Feminist Liberation Psychology and the Contours of Agency in the Margins', Feminism \& Psychology, 19(3), pp. 298-312.

Cox, Kevin R. (1989) 'The Politics of Turf and the Question of Class', in Jennifer Wolch \& Michael Dear (eds.), The Power of Geography: How Territory Shapes Social Life, Boston: Unwin Hyman, pp. 61-90.

Das, Veena (2007) Life and Words: Violence and the Descent into the Ordinary, Berkeley, Los Angeles \& London: University of California Press.

de Certeau, Michel (1984) The Practice of Everyday Life, Berkeley: University of California Press. Ehrenreich, Robert M.; Cole, Tim (2005) 'The Perpetrator-Bystander-Victim Constellation: Rethinking Genocidal Relationships', Human Organization, 64(3), Fall, pp. 213-24.

Foucault, Michel (1984) Histoire de la sexualité III: Le souci de soi. Paris: Gallimard.

Foucault, Michel (2004) Surveiller et punir: Naissance de la prison, CopyLeft Yuji, [1975].

Gayer, Laurent (2003) ‘A Divided City: 'Ethnic' and 'Religious' Conflicts in Karachi, Pakistan', http://www.ceri-sciencespo.com/archive/mai03/artlg.pdf.

Gayer, Laurent (2004) 'Karachi : Violences et globalisation dans une ville-monde', Raisons politiques, 15, August, pp. 37-51.

Gayer, Laurent (2007) ‘Guns, Slums, and 'Yellow Devils': A Genealogy of Urban Conflicts in Karachi, Pakistan', Modern Asian Studies, 41(3), pp. 515-544.

Haq, Farhat (1995) 'Rise of the MQM in Pakistan: Politics of Ethnic Mobilization', Asian Survey, 35 (11), November, pp. 990-1004.

Haq, Farhat (2007) 'Militarism and Motherhood: The Women of the Lashkar-i-Tayyaba in Pakistan', Signs, 32(4), Summer, pp. 1023-46.

Hasan, Arif (1999) Understanding Karachi: Planning and Reform for the Future, Karachi: City Press, [2 ${ }^{\text {nd }}$ edn]. 
Hussain, Akmal (1990) 'The Karachi Riots of December 1986: Crisis of State and Civil Society in Pakistan' in Veena Das (ed.), Mirrors of Violence: Communities, Riots and Survivors in South Asia, Oxford: Oxford University Press, pp. 185-93.

Jain, Sarah S. Lochlann (2004) 'Dangerous Instrumentality': The Bystander as Subject in Automobility', Cultural Anthropology, 19(1), pp. 61-94.

Jeganathan, Pradeep (2000) 'A Space for Violence: Anthropology, Politics and the Location of a Sinhala Practice of Masculinity’ in Partha Chatterjee \& Pradeep Jeganathan (eds.), Community, Gender and Violence: Subaltern Studies XI, New York: Columbia University Press, pp. 37-65.

Kennedy, Charles H. (1991) ‘The Politics of Ethnicity in Sindh', Asian Survey (31)10, October, pp. 38-955.

Khan, Ayesha (2003) ‘Gendering War Talk’, International Feminist Journal of Politics, 5(3), November, pp. 448-455.

Khan, Naveeda (2006) 'Of Children and Jinn: An Inquiry into an Unexpected Friendship during Uncertain Times', Cultural Anthropology, 21(2), pp. 234-64.

Khan, Nichola (2010a) Mohajir Militancy in Pakistan: Violence and Transformation in the Karachi Conflict, New York: Routledge.

Khan, Nichola (2010b) 'Violence, Anti-Convention and Desires for Transformation amongst Pakistan's Mohajirs in Karachi', Cultural Dynamics, 22 (3), pp. 225-45.

Khan, Nichola (2010c) 'Time and Fantasy in Narratives of Jihad: The Case of the Islami Jamiat-iTuleba in Karachi', Human Affairs, 20, pp. 241-48.

Mahmood, Saba (2005) Politics of Piety: The Islamic Revival and the Feminist Subject, Princeton: Princeton University Press.

Malik, Iftikhar H. (1996) 'The State and Civil Society in Pakistan: From Crisis to Crisis', Asian Survey, 36(7), July, pp. 673-90.

Naqvi, Tahir Hasnain (2006) Interregnal politics: Autocracy and Counternationalism in Urban Pakistan, Ph.D. dissertation, Berkeley, University of California.

Nasr, Seyyed Vali Reza (1994) The Vanguard of the Islamic Revolution: The Jama'at-i Islami of Pakistan, Berkeley: University of California Press.

Putnam, Robert D. (2000) Bowling Alone: The Collapse and Revival of American Community, New York: Simon and Schuster.

Ring, Laura (2006) Zenana: Everyday Peace in a Karachi Apartment Building, Bloomington: Indiana University Press.

Scheper-Hughes, Nancy (2008) 'A Talent for Life: Reflections on Human Vulnerability and Resilience', Ethnos, 73(1), March, pp. 25-56.

Shah, Alpa (2006) 'Markets of Protection: The 'Terrorist' Maoist Movement and the State in Jharkand, India', Critique of Anthropology, 26(3), pp. 297-314.

Shah, Alpa (2009) 'In Search of Certainty in Revolutionary India', Dialectical Anthropology, 33(3-4), pp. 271-86.

Shaheed, Farida (1990) ‘The Pathan-Muhajir Conflicts 1985-6: A National Perspective', in Veena Das (ed.), Mirrors of Violence: Communities, Riots and Survivors in South Asia, Oxford: Oxford University Press, pp. 194-214. 
Sipe, Keith Raymond (1976) Karachi's Refugee Crisis: the Political Economic and Social Consequences of Partition-Related Migration, PhD. dissertation, Duke University, Ann Arbor: UMI.

Staub, Ervin (1989) The Roots of Evil: The Origins of Genocide and Other Group Violence. New York: Cambridge University Press.

Staub, Ervin (1996) 'Preventing Genocide: Activating Bystanders, Helping Victims, and the Creation of Caring,' Peace and Conflict: Journal of Peace Psychology, 2(3), pp. 189-200.

Supreme Court of Pakistan (2011) Judgement, suo motu case no. 16 of 2011: Suo Motu Action regarding law and order situation in Karachi. October 6, 2011. (http://geo.tv/ important_events/2011/SC_verdict_karachi/SMC16of2011_detailed_judgment.pdf, accessed October 23 2011).

Tambiah, Stanley J. (1996) Leveling Crowds: Ethnonationalist Conflicts and Collective Violence in South Asia, Berkeley \& Los Angeles: University of California Press.

Verkaaik, Oskar (1994) A People of Migrants: Ethnicity, State and Religion in Karachi, Amsterdam: VU University Press.

Verkaaik, Oskar (2004) Migrants and Militants: Fun and Urban Violence in Pakistan, Princeton \& Oxford: Princeton University Press.

Verkaaik, Oskar (2009) 'At Home in Karachi: Quasi-Domesticity as a Way to Know the City', Critique of Anthropology, 29(65), pp. 65-80.

Vetlesen, Arne Johan (2000) 'Genocide: A Case for the Responsibility of the Bystander', Journal of Peace Research, 37(4), pp. 519-32.

Vetlesen, Arne Johan (2005) Evil and Human Agency: Understanding Collective Evildoing, New York: Cambridge University Press.

Vigh, Henrik (2006) Navigating Terrains of War: Youth and Soldiering in Guinea-Bissau, New York: Berghahn Books.

Zaidi, S. Akbar (1997) 'Politics, Institutions, Poverty: The Case of Karachi', Economic and Political Weekly, 32(51), pp. 3282-93.

\section{NOTES}

1. On 'resilience,' see Scheper-Hughes 2008.

2. See notes 7 and 8 , below.

3. Drawing analytical attention to those who wait, seek refuge and reject by avoiding violence builds on a host of scholarship emphasizing how agency is located in normativity and subjection, rather than exclusively in forms of oppositional resistance (e.g. Berlant 2008, Butler 1997, Foucault 2004[1975], 1984, Mahmood 2005).

4. Widely employed in psychology, the 'bystander effect' addresses the problem of why people are less likely to help or intervene in a situation with multiple onlookers. Conversely, anthropologists of violence have criticized the 'anthropologist-as-bystander' to assert the impossibility of allegedly objective political distance from local entanglements. Both of these approaches fault the inaction or conceit of the bystander.

5. For example, Robert Ehrenreich and Tim Cole (2005) distinguish between bystanders who may resist, acquiesce to, inhibit, instrumentalize while opposing, or not participate while opposing perpetrators' actions (Ehrenreich \& Cole 2005: 218). In addition, they note that benefits, 
economic or otherwise, are useful to consider independently of personal political support or opposition (Ehrenreich \& Cole 2005: 218).

6. Alpa Shah describes this as a problem of uncertainty, where political affiliates seek 'epistemic clarity-the possibility that on the other side norms and relationships will be more certain. This is a certainty carved out of uncertainty and ambivalence, a certainty that denies or projects away uncertainty' (2009: 284-5).

7. Another key area of analysis is the legality and illegality of land settlements and development, pioneered by urban planning scholars such as Jan van der Linden, Arif Hasan and Noman Ahmed. An emergent scholarship explicitly connects political violence with this history and context of land use, e.g. Budhani et al. 2010, Gayer 2003, 2007.

8. Initially used as a religious term for the early Muslims who fled from Mecca to Medina during the hijrat, the term Muhajir was mobilized to refer to the Muslim migrants who left India to settle in Pakistan at Partition (e.g. Ansari 2005: 10, Sipe 1976, Verkaaik 2004: 45-47). Oskar Verkaaik observes that, more colloquially, Muhajirs were thought of as mobile, rootless, and as those who had left tradition behind in the act of migration (2004: 41-49). Thus, the ethno-political designation of the category 'Muhajir' activated by the MQM, in the early years of the party, compounded the religious implications of the term for the hijrat, a sensibility for the sacrifices made for Pakistan through the processes of migration, and the vociferous declaration of 'exprivilege' (Berlant 1997: 2) following increasing mobilization of ethnic identity politics: Sindhi, Punjabi, Pakhtun (cf. Verkaaik 2004: 20-63). By at least the late 1990s, the term Muhajir was most powerfully associated with MQM politics and its particular tactics of instrumentalizing identity, in spite of the term having been officially erased from the party rhetoric in 1997.

9. This scholarship is quite extensive. My references here draw largely on anthropologists or researchers using field research methods. Notable examples include political analyses focusing on ethnic identity politics and political violence (Ahmed 1998, Gayer 2004, 2007, Haq 1995, Hussain 1990, Kennedy 1991, Malik 1996, Shaheed 1990, Tambiah 1996), party activists and violence (Nichola Khan 2010a, 2010b, Verkaaik 1994, 2004, 2009) and Muhajir women who lost family members during the course of turf wars and state repression of the MQM, described as both victims and survivors (Chaudhry 2004, Chaudhry \& Bertram 2009, Ayesha Khan 2003). Print journalism between 1985 and 1995, notably in the Karachi-based weekly English language news magazine Herald, is especially informative, analytically rich, and regularly cited in the scholarship cited above.

10. The Pakistan People's Party (PPP) is a secular, socialist-leaning party with a strong power base in Sindh. The party leadership has consistently been occupied by members of the Sindhi landowning Bhutto family, including the current President of Pakistan Asif Ali Zardari, widower of the former leader Benazir Bhutto.

11. See Vigh (2006) for an interesting discussion of the 'everydaying' of ongoing political and economic crisis in terms of routinization as 'the social metamorphosis of change into perceived continuity' and its sedimentation into habitus over time (Vigh 2006: 153-4).

12. The Jamaat-i-Islami (JI) and the MQM have both historically drawn on support from communities and descendants of Partition-era migrants. Their enmity extends to the student wings of the respective parties. The student wing of the Jamaat-i-Islami is known as the Islami Jamiat-i-Talaba (IJT), and the student wing of the MQM is the All-Pakistan Muttahida Students Organization (APMSO). Until 1997, the APMSO was formerly known as the All-Pakistan Muhajir Students Organization, in tandem with the ethnic name of the MQM. The JI is an explicitly Muslim party that advocates for Sharia law and is described by scholars as modernist and Islamist. Nichola Khan (2010a) gives a brief overview of the contours of JI-MQM animosity. For more on the history of the JI in Pakistan, see e.g. Nasr (1994).

13. Between July and August 2011, when hundreds of casualties and injuries were reported in more outlying neighborhoods, only two dead bodies in telltale gunny sacks were found in 
Nazimabad. See, e.g. the Supreme Court judgment on the suo moto case regarding law and order in Karachi, delivered October 6, 2011 (2011: 30).

14. For more detail on this planning scheme, see Hasan (1999: 26-7).

15. See the information provided by the City District Government of Karachi website ( http://14.192.147.139/CDGK/Portals/0/TownMaps/NewKarachi_Map_Large.jpg, accessed October 23 2011).

16. The Supreme Court judgment on the widespread political violence in Karachi between July and August 2011 maintained that the political dynamic in the area has shifted; violent confrontations now occur among politicized groups of Sunni Muslims, between the Barelvi Sunni Tehreek and the Deobandi Sipah-e-Sahaba (2011: 27).

17. Naqvi (2006) describes these personal competencies as hesiyat, a term for which my informants used 'status' as a gloss.

\section{ABSTRACTS}

This article posits an analytic of the bystander, as a supplement to studies of perpetrators and victims, in relation to political affiliation, mobilization and violence in Karachi. In particular, I use ethnographic findings to elucidate the tactics of anticipation used by Karachi residents of neighborhoods widely considered the turf of the Muttahida Qaumi Movement (MQM). The examples of students' and teachers' reactions to a college rumble between rival groups, parents' attempts to keep their sons from being recruited into party politics, and young people confident in their ability to navigate an economy of affiliation demonstrate a range of bystander tactics, in which subjection and subversion are aligned. Although metanarratives of democratization frequently elide the everyday activity of standing by, it constitutes a pervasive mode of participation in Karachi's political landscape.

INDEX

Keywords: Karachi, political parties, violence, bystanders, participation, anthropology, MQM

\section{AUTHOR}

\section{TANIA AHMAD}

Assistant Professor of Anthropology, Franklin \& Marshall College, Lancaster, Pennsylvania 